\title{
DESKRIPSI KONTEKS ISI TARI PIRING GELAS DI SANGGAR SILAMPARI KABUPATEN MUSI RAWAS
}

\author{
Oleh: \\ WIKE \\ (Guru Seni Budaya SMP Baptis Kota Palembang)
}

\begin{abstract}
Abstrak
Konteks isi tari Piring Gelas adalah sebuah bentuk yang nampak secara empirik struktur luarnya yang mengandung makna dan isi tari. Oleh karena itu, kesulitan yang sering muncul dalam melihat dan mendeskripsikan makna tari Piring Gelas. Berdasarkan hal tersebut maka masalah penelitian ini adalah bagaimanakah deskripsi konteks isi tari Piring Gelas di Sanggar Silampari Kabupaten Musi Rawas. Tujuan penelitian ini adalah untuk mengetahui deskripsi konteks isi tari Piring Gelas di Sanggar Silampari Kabupaten Musi Rawas. Metode yang digunakan dalam penelitian ini adalah metode deskriptif kualitatif. Penelitian ini dilakukan di Sanggar Silampari Kabupaten Musi Rawas, dengan data yang berupa kata-kata, uraian dan gambar yang mengenai tari Piring Gelas sebagai konteks isi. Hasil Penelitian menunjukan bahwa tari Piring Gelas adalah salah satu tari tradisonal yang ada di Kabupaten Musi Rawas dengan menginjak tumpukan piring dan gelas. Tari Piring Gelas memiliki konteks isi sebagai tema gerak adalah kesabaran gerak-gerak pada tari Piring Gelas gerak hormat, salam, selyang, selayang, main seledang, mengangkat piring, berputar, transisi dan naik piring, konteks isi sebagai tema cerita lebih dekat dengan tipe dramatik dan konteks isi sebagai tema simbolik terlihat dari tata rias dan busana, tempat panggung, penari, properti serta gerak dalam tari Piring Gelas di Kabupaten Musi Rawas.
\end{abstract}

\section{Kata kunci: Tari Piring Gelas, Konteks Isi}

\section{A. PENDAHULUAN}

Kabupaten Musi Rawas adalah salah satu Kabupaten di Provinsi Sumatera Selatan yang memiliki kekayaan sumber daya alam dan seni budaya yang lain dan berbeda dengan daerah-daerah yang ada di seluruh wilayah Indonesia. Masyarakat Kabupaten Musi Rawas tergolong dalam masyarakat agraris, dimana sebagian besar penduduknya bermata pencaharian sebagai petani padi, karet, kopi, kelapa sawit serta sebagian peternak ikan air tawar. Kabupaten Musi Rawas terletak di sebelah barat hulu sungai Musi dan sepanjang sungai Rawas. Di sebelah utara berbatasan dengan Provinsi Jambi dan Kabupaten Musi Rawas Utara di selatan berbatasan dengan Kabupaten Musi Banyuasin, Kabupaten Empat lawang, di bagian barat berbatasan dengan Provinsi Bengkulu. Kabupaten Musi Rawas memiliki keberanekaragaman seni budaya, baik dari Kabupaten Musi Rawas sendiri maupun 
dari luar daerah Musi Rawas, karena masyarakatnya sebagian besar adalah transmigran yang berasal dari pulau Jawa.

Seiring dengan perkembangan jaman, budaya tumbuh di tengah-tengah masyarakat yaitu sebuah tradisi kerakyatan di setiap daerah yang menjadikan Seni sebagai hiburan, ritual, upacara adat, penyambutan tamu, sehingga Seni bisa dikenal oleh masyarakat. Sartono (2014:6) Seni adalah sesuatu yang memuat hal-hal yang transendental, sesuatu yang tidak kita kenal sebelumnya, dan kini kita kenal melalui karya seorang seniman. Seni dibagi dalam 5 (Lima) cabang, yakni, seni musik, seni tari, seni rupa, seni sastra dan teater.

Pertunjukan kesenian, upacara adat, penyambutan tamu yang dilakukan oleh sebuah komunitas pada saat melakukan upacara adat, penyambutan tamu serta ritualritual lainya yang dilakukan dengan sebuah kesenian yang melahirkan beberapa seni pertunjukan sesuai dengan latar belakang kebudayaan masing-masing daerah. Masyarakat tradisional seni pertunjukan dijadikan sebagai ekspresi tingkah laku manusia, baik menyangkut konflik yang di alami maupun cara penyelesaian konflik. Seni pertunjukan dijadikan ekspresi manusia agar mampu menciptakan keserasian antara manusia dan lingkungannya. Selain itu seni pertunjukan sebagai proses ritual, dimana aturan, makna serta kekuatan (magis) yang terkandung dari seni pertunjukan lebih diutamakan. Dengan kepercayaan pada magis masyarakat petani pedesaan di Kabupaten Musi Rawas, sebagai contoh adalah kesenian tari Piring Gelas yang terdapat di Kabupaten Musi Rawas Provinsi Sumatera Selatan.

Kesenian tari Piring Gelas merupakan salah satu kesenian rakyat yang berkembang di Kabupaten Musi Rawas Provinsi Sumatera Selatan sampai saat ini. Tari Piring Gelas memiliki keunikan yang tidak terdapat di wilayah kabupaten manapun. Keunikan pertunjukan tari Piring Gelas di Kabupaten Musi Rawas ini, terletak pada kesederhanaan, keluwesan, dan keaslian gerakan tari yang masih sangat tradisional, serta ketika penari melakukan pertunjukan menari di atas tumpukan piring dan gelas.

Sebuah koreografi atau tari tidak akan lepas dengan konteks isi dari tarian tersebut. Menurut Hadi (2011:55) pendekatan konteks isi (content) artinya melihat bentuk atau sosok tarian yang nampak secara empirik struktur luarnya (surface structure) senantiasa mengandung arti dari "isi" (content) atau "struktur dalamnya" (deep structure). Tari Piring Gelas memiliki bentuk yang memiliki beberapa motif dalam gerakan yang memiliki makna atau isi dari setiap motif tersebut. Setiap gerakan memiliki makna dan cerita yang tersirat, banyak masyarakat menyaksikan pertunjukan tari Piring Gelas tetapi konteks isi dari tari Piring Gelas tersebut tidak mengetahui karena tidak memahami proses ketidaknampakan dari 
pengaturan masalah-masalah batin menjadi isi dan hanya sebatas hiburan.

Berdasarkan fenomena tersebut, pentingnya pengenalan konteks isi tari Piring Gelas di Kabupaten Musi Rawas agar masyarakat tahu makna dari tari Piring Gelas dan sebagai putra-putri daerah Kabupaten Musi Rawas merasa berkewajiban untuk menjaga dan melestarikan kesenian yang ada di daerah sendiri terdapat banyak nilai yang ada dalam seni terutama seni tari yang didalamnya masyarakat tidak mengetahui mulai dari tema gerak, tema cerita dan tema simbolik dalam penataan atau penyusunan tari oleh koreografi. Dan mengenalkan pada masyarakat bahwa tari Piring Gelas memiliki konteks isi yang dapat dipahami secara verbal.

\section{B. METODE PENELITIAN}

Metode penelitian yang digunakan adalah deskriptif kualitatif, dengan sumber data dokumen dan informan. Tempat penelitian di Sanggar Silampari, Kabupaten Musi Rawas. Teknik pengumpulan data melalui wawancara, observasi langsung dan kajian dokumen. Sedangkan Validitas data guna memperoleh hasil data yang maksimal terjabarkan dalam proses pemaparan hasil penelitian, pembahasan dan penarikan simpulan. Dengan adanya validitas data triangulasi yang digunakan: triangulasi data, triangulasi metode.

\section{PEMBAHASAN DAN HASIL PENELITIAN}

\section{1) Tari Piring Gelas}

Tari Piring Gelas, adalah tari tradisional dari Kabupaten Musi Rawas yang telah ada sejak zaman sebelum kemerdekaan, diciptakan oleh para sesepuh atau seniman daerah yang sampai sekarang tidak diketahui namanya. Kesenian tari Piring Gelas yang terdapat di Kabupaten Musi Rawas Provinsi Sumatera Selatan, kesenian tari Piring Gelas merupakan salah satu kesenian rakyat yang berkembang di Kabupaten Musi Rawas Provinsi Sumatera Selatan sampai saat ini. Orang biasa mengenal kesenian tari Piring Gelas yang terdapat di Kabupaten Musi Rawas Provinsi Sumatera Selatan, karena tari Piring Gelas ini memiliki keunikan yang tidak terdapat di wilayah kabupaten manapun.

Umumnya yang menjadi penari biasanya hanya terdiri dari dua ( 3 ) orang perempuan, ada satu syarat yang harus dipenuhi oleh seorang penari tari Piring Gelas, yaitu harus seorang wanita yang masih gadis atau lajang, atau belum pernah menikah. Syarat ini harus diberitahukan kepada masyarakat agar dalam menari tidak terjadi gangguan atau kesalahan fatal, misalnya penari akan jatuh ketika menaiki tumpukan piring dan gelas. Tari Piring Gelas biasanya dipentaskan pada siang hari sekitar pukul 09.00 sampai 11.00" atau malam hari pada pukul 19.00 sampai 20.30 malam, dan bisa dipentaskan kapan saja sesuai dengan jadwal 
dan kepentinganya. Dalam satu tahun, kesenian tari Piring Gelas bisa pentas lebih dari 5 kali. Tetapi tidak menutup kemungkinan satu tahun sampai pentas 12 bahkan 15 kali (hasil wawancara pada observasi,16 Januari 2018, Hamam Santoso).

Tari Piring Gelas dipentaskan di pangung-panggung pesta perkawinan, sunatan pencukuran bahkan pada acara-acara kenegaraan. Penari Piring Gelas bisa berjumlah satu, dua, atau tiga orang perempuan, dan tujuh orang pemain musik tanpa menggunakan vokalis.

\section{2) Konteks Isi Tari Piring Gelas}

Tari memiliki teks dan konteks yang mana tidak terlepas tetapi pandangan masyarakat yang ada di Kabupaten Musi Rawas hanya melihat teks nya saja. Dalam tari Piring Gelas tentunya memiliki konteks atau makna dari tarian tersebut, banyak makna yang terkandung dalam tari Piring Gelas. Sedangkan menurut Attay Mochtar selaku pemilik sanggar Silampari menyatakan bahwa tari Piring Gelas memiliki banyak filosofi yang belum terlihat oleh masyarakat. Tari Piring Gelas tari yang memiliki ketenangan dalam menarikan dan dalam ketenangan itu ada makna tertentu dalam tari Piring Gelas. Menurut M. Kudusuntuk selaku budayawan tari Piring Gelas di Kabupaten Musi Rawas menyatakan bahwa seni tari Piring Gelas selain memiliki keunikan menginjak piring bertingkat dan ada makna di setiap menarikan tari Piring
Gelas ini.

Menurut Hadi (2011:55) pendekatan konteks isi (content) artinya melihat bentuk atau sosok tarian yang nampak secara empirik struktur luarnya (surface structure) senantiasa mengandung arti dari "isi" (content) atau "struktur dalamnya" (deep structure). Kebentukan dari ketiga elemen gerak-ruangwaktu secara bersama-sama elemen-elemen itu mencapai visilitas estetis kebentukan koreografi sebagai konteks isi.

Sesungguhnya yang paling penting dalam koreografi isi haruslah dihasilkan dari kehendak sang koreografer, yang efek-efek kebentukannya perlu diterampilkan, sehingga memerlukan teknik mewujudkan sosok koreografi. Menurut Hadi (2011:58) Koreografi kontek isi dapat dibedakan menajadi tiga : konteks isi sebagai tema gerak, konteks isi sebagai tema cerita dan konteks isi sebagai tema simbolik.

\section{3) Konteks isi sebagai Tema Gerak Menurut Rochayati (2016:12) tema} tari dapat dipahami sebagai pokok arti permasalahan yang mengandung sesuatu maksud atau motivasi tertentu. Tema merupakan suatu gagasan atau ide pikiran mengenai segala sesuatu yang diimajinasi maupun nyata dirasakan seorang penari. Menurut Hadi (2011:60) seorang penari harus mengekspresikan dengan jelas keunikan gerak yang telah ditetapkan, dan gerakan yang 
berlebihan yang secara langsung sudah diperhitungkan dengan tema gerakannya.

Tari Piring Gelas merupakan sebuah tari tradisi yang ada di Kabupaten Musi Rawas yang memiliki gerak yang sederhana tetapi memiliki makna. Tari Piring Gelas adalah sebuah kesenian tradisional yang memiliki khas daerah setempat. Meskipun tari ini merupakan tari tradisional bukan merupakan garapan baru yang hasil bentuk penyajiannya sangat dihitungkan, tari Piring Gelas memiliki gerakan yang sangat sederhana tetapi memiliki makna tertentu dalam gerakan demi gerakan tari Piring Gelas tersebut. Tidak hanya garapan baru atau sebuah tari dengan konsep kontemporer saja yang memiliki tema tetapi tari tradisional memiliki tema yang jelas dan terlihat dari seorang penari yang menarikan tari Piring Gelas.

Tari Piring Gelas memiliki beberapa gerak yang memiliki tema. Tema gerak tari Piring Gelas antara lain :

Gerak Hormat, dalam tari Piring Gelas gerak hormat memiliki arti sebuah kesopanan terhadap penonton. Kesopanan itu ditunjukan sebagai ucapan terima kasih telah datang dan ikut serta menyaksikan tari Piring Gelas yang akan ditampilkan.

Salam, dalam tari Piring Gelas gerak salam juga sama artinya dengan gerak hormat yang memiliki arti kesopanan untuk menyapa kepada penonton yang telah hadir.

Selyang, dalam tari Piring Gelas gerak Selyang memiliki tema keanggunan para penari dalam menarikan sebuah tari Piring Gelas sebelum menyusun dan menata piring dan gelas secara bertumpuk. Keanggunan terlihat dari gerakan serta para penari yang sangat cantik melambangkan bahwa masayarakat Musi Rawas memiliki penduduk perempuan yang anggun dan sopan dalam apapun

Selayang, dalam tari Piring Gelas gerak selayang memiliki arti yang sama dengan gerakan selyang.

Main Selendang, dalam tari Piring Gelas gerak main Selandang memiliki tema sebagai terbang karena pada zaman dahulu di salah satu sungai datanglah bidadari yang mandi dan lalu diambil selendang maka dari itu bumi Musi Rawas sebelum pemekaran dikatakan sebagai Bumi Silampari.

Mengangkat Piring, dalam tari Piring Gelas gerak mengangkat piring adalah dimana gerakan akan menyusun sebuah piring untuk dinaikkan oleh penari dengan penuh hati-hati.

Berputar, dalam tari Piring Gelas gerakan berputar merupakan sebuah gerakan dasar yang dilakukan penari utama untuk melihat kesiapan susunan piring dan gelas sebelum menaik tumpukan piring dan gelas.

Transisi, dalam tari Piring Gelas transisi memiliki arti bahwa susunan piring dan gelas telah disusun sehingga penari utama akan segera menaikkan tumpukan piring dan gelas. Naik Piring, dalam tari Piring Gelas gerakan menaik piring memiliki tema kesabaran yang dimana dalam menaikkan piring, penari haruslah berhati-hati dan menjaga 
keseimbangan agar penari tidak jatuh.

\section{4) Konteks Isi sebagai Tema Cerita}

Menurut Hadi (2011:62) konteks isi sebagai tema cerita dalam sebuah tari atau koreografi sering disebut dengan literal. Artinya pokok permasalahan yang mengandung "isi" dari tarian atau koreografi esensinya adalah "tema cerita" tertentu, baik disajikan dalam bentuk atau tipe dramatari atau sendratari, dramatik, liris, maupun tipe komikal.

Menurut Widyastutieningrum dan Wahyudiardo (2014:58) tema cerita yang baik adalah tema yang orisinal. Dengan tema orisinal maka tema cerita dalam tari semakin menambah nilai yang terkandung tetapi ketika tema cerita tari telah dicampurkan oleh budaya lain maka tema cerita tari bukan orisinal lagi.

Tari Piring Gelas merupakan sebuah tarian tradisional yang ada di Kabupaten Musi Rawas yang memiliki keunikan dengan menaikkan piring dan gelas secara bertumpuk. Tari Piring Gelas secara keseluruhan tidak memiliki cerita khusus yang melambangkan adegan demi adegan. Tari Piring Gelas adalah sebuah tarian nonliteral yang artinya secara keseluruhan tari Piring Gelas hanya disajikan tanpa adanya konflik, adegan bahkan klimaks seperti tari konsep baru literal. Akan tetapi, tari Piring Gelas hampir mendekati dengan tipe dramatik yang dimana seorang penari menaikkan sebuah tumpukan piring dan gelas secara bertingkat dengan penuh kehati-hatian dalam menaikkan sebuah piring dan gelas tersebut. Ketegangan terjadi ketika penari membawakan piring di tangan kanan dan kiri lalu menaikkan sebuah tumpukan piring dan gelas satu persatu sehingga keteganggan terjadi ketika penari menaikkan tumpukan piring tertinggi dalam tumpukan piring dan gelas.

Tari Piring Gelas memiliki tema besar yaitu tema dari tari Piring Gelas adalah kesabaran. Kesabaraan dalam tari Piring Gelas terlihat dalam penari menaiki sebuah tatakan piring dan gelas secara hati-hati dan penuh kesimbangan. Akan tetapi kesabaran merupakan tema secara keseluruhan, dalam gerak ada lagi yang berkaitan dengan tema. Gerak Selyang dan Selayang memiliki tema keanggunan para penari dalam menarikan sebuah tari Piring Gelas sebelum menyusun dan menata piring dan gelas secara bertumpuk. Keanggunan terlihat dari gerakan serta para penari yang sangat cantik melambangkan bahwa masayarakat Musi Rawas memiliki penduduk perempuan yang anggun dan sopan dalam apapun. Gerak Main Selandang memiliki tema sebagai terbang karena pada zaman dahulu di salah satu sungai datanglah bidadari yang mandi dan lalu diambil selendang maka dari itu bumi Musi Rawas sebelum pemekaran dikatakan sebagai Bumi Silampari. Gerakan selyang dan selayang sangat berkaitan dengan gerakan main selendang dikarenakan sifat gerakan selyang dan selayang mencerminkan bidadari yang ada dengan sifat yang baik dan anggun. 
Gerak mengangkat piring, berputar dan transisi memiliki tema kesabaran dalam mengangkat piring karena jika mengangkat piring terburu-buru maka akan terjadi sesuatu diperlukan kesabaran yang ekstra begitu juga dengan menaikkan piring dan gelas secara bertumpuk. Kesabaran terlihat dalam menaikkan tari Piring Gelas secara bertingkat mulai dari rendah sedang bahkan tertinggi dengan tumpukan piring dan gelas secara bergantian. Kesabaran merupakan sebuah prinsip dalam kehidupan masyarakat Musi Rawas menuju Darussalam dan sebuah motto dalam menjunjung tinggi adat istiadat Musi Rawas. Dalam tari Piring Gelas hanya satu orang yang menaikkan sebuah piring dan gelas, 2 penari lain duduk didepan tumpukan tari Piring Gelas dengan menyusun piring dan gelas. Darisana terlihat kesabaran seorang penari yang harus bersabar dalam menyusun piring dan gelas agar tidak terjadi insiden atau kejadian yang mengakibat penari inti untuk menaikkan tumpukan tari Piring Gelas tersebut. Setelah tersusun rapi maka penari inti mulai menaikkan sebuah piring dan gelas yang bertumpuk bertingkat. Tema besar kesabaran dalam tari Piring Gelas sangat tepat dalam konteks isi sebagai tema gerak karena penari melakukan hal-hal yang sangat penuh kesabaran, tidak hanya penari merasakan kesabaran dalam menarikan tari Piring Gelas tetapi pemain musik juga bersabar dalam memainkan musik saat penari menginjak tari piring dan gelas secara bertumpuk baru mulai musik berikutnya. Jadi konteks isi sebagai tema gerak tari Piring Gelas memiliki tema kesabaran dalam menarikan tari Piring Gelas secara bertumpuk, kesabaran menaikkan piring dan gelas penuh dengan konsentrasi.

Jadi untuk konteks isi sebagai tema cerita tari Piring Gelas memiliki tema cerita yang tidak jelas arahnya karena tidak memiliki konflik seperti garapan baru karena tari Piring Gelas merupakan tari tradisional yang secara keseluruhan tidak memiliki konflik. Tari Piring Gelas memiliki klimaks ketika penonton melihat bagaimana Piring Gelas tersebut tidak jatuh ketika di naikkan oleh penari dan ada rasa ketegangan dalam menarikan maupun menonton tari Piring Gelas tersebut. Tipe dramatik adalah suatu tipe cerita yang tepat yang mana tari Piring Gelas tidak jelas alurnya karena dalam menarikan tari Piring Gelas penari mengalir saja tanpa adanya alur cerita yang panjang. Akan tetapi, ada dramatik dalam menarikan Piring Gelas yaitu seorang penari perempuan berani menaiki tumpukan piring dan gelas secara bertingkat dengan rasa tegang dan penuh konsentrasi.

\section{5) Konteks Isi Sebagai Tema Simbolik}

Menurut Hadi (2011:65) konteks isi sebagai tema-tema bersifat simbolis dalam bentuk tari atau koreografi sungguh sangat "luas" dan "dalam" nilai dan pemaknaannya. Oleh karena itu konteks isi sebagai tema-tema simbolik merupakan respresentasi "mental" dari 
subyek, yaitu wahana konsepsi manusia tentang obyek, sehingga tema-tema yang bersifat simbolik, semata-mata tidak menunjuk pada bendanya, tetapi lebih kepada konsepnya.

Tari Piring Gelas memiliki sebuah konteks isi sebagai tema simbolik yang terlihat beberapa aspek yang dilihat. Aspek-aspek tersebut mendukung tema simbolik dalam tari Piring Gelas. Berikut aspek-aspek yang mendukung tari Piring Gelas sebagai tema simbolik :

\section{a. Kostum/Tata Rias dan Busana}

Kostum sebagai salah satu aspek yang mendukung dalam tari Piring Gelas dan juga memiliki makna serta menjadi simbolis dalam tari Piring Gelas. Kostum yang dipakai dalam tari Piring Gelas adalah kostum adat tradisional yang ada di Kabupaten Musi Rawas. Kostumnya berupa baju kurung dan songket yang dikenakan oleh penari yang melambangkan sebuah keanggunan penari dalam menarikan tari Piring Gelas. Serta aksesoris yang dipakai oleh penari Piring Gelas menunjukan seseorang bidadari yang turun dari langit dengan keanggunan dan kecantikan yang luar biasa. Serta tata rias dalam tari Piring Gelas menggunakan tata rias cantik yang melambangkan sebuah kecantikan dari bidadari.

\section{b. Tata Panggung}

Tata panggung yang digunakan dalam pementasan tari Piring Gelas biasanya menggunakan lapangan, panggung terbuka atau di alam terbuka dengan landasan atau dasar stage yang rata dan tidak bergoyang / mantap. Hal ini merupakan syarat mutlak karena bila panggung dalam keadaan tidak rata dikhawatirkan penari akan mengalami kesulitan dan jatuh ketika akan menari di atas tumpukan piring dan gelas.

\section{c. Penari}

Penari tari Piring Gelas berjumlah 3 orang perempuan yang masih perawan tetapi pada perkembangan zaman penari tari Piring Gelas berjumlah 5 orang yang terdiri 3 perempuan serta 2 laki-laki. Laki-laki tugasnya membawa gelas dan piring sedangkan perempuan melakukan gerak tari Piring Gelas. Penari perempuan harus masih perawan karena syarat mutlak agar tidak terjadi apa-apa dalam menaikkan tumpukan piring dan gelas.

\section{d. Properti}

Tari Piring Gelas memiliki properti yan digunakan dalam tari. Properti tersebut berupa piring dan gelas yang secara bertumpuk piring dan gelas. Piring dalam masyarakat Kabupaten Musi Rawas melambangkan tempat makan manusia selain dari daun dan benda lain. Simbol-simbol tersebut terlihat jelas dengan tumpukan Piring dan Gelas secara bertumpuk mulai dari rendah hingga tinggi dan kembali rendah lagi. Simbol tersebut menjelaskan bahwa Kabupaten Musi Rawas memiliki dataran rendah dan tinggi yang sangat luas. Selain melihat dari tersebut, ada makna lain yang melambangkan tingkatan manusia dari mulai hidup sederhana ketika memiliki kerja 
keras dalam kehidupan maka stratanya akan meningkat dan akan ada fase kejayaan dalam kehidupan. Ketika fase kejayaan dalam kehidupan maka manusia harus ingat akan usaha sebelum mengalami fase kejayaan.

Tari Piring Gelas memiliki simbol piring karena daerah kabupaten Musi Rawas letak geografisnya terletak berdekatan dengan Provinsi Sumatera Barat. Pengaruh dari kebudayaan Minangkabau inilah menjadi salah satu keanekaragaman yang ada di Kabupaten Musi Rawas. Selain piring, simbol yang terdapat pada tari Piring Gelas adalah Gelas yang artinya tempat minum bagi manusia yang banyak dipakai oleh masyarakat Kabupaten Musi Rawas.

Dengan kekayaan alam yang melimpah, dengan sungai kelingi yang sangat luas maka masyarakat tidak pernah kekurangan air dalam kehidupan. Jadi konteks isi sebagai tema simbolik yang ada di tari Piring Gelas terdapat pada properti yang ada dalam tarian Piring Gelas.

Gerak

Gerak merupakan sebuah aspek yang simbol sangat melekat dalam tari apapun. Dalam tari Piring Gelas ada beberapa gerakan yang merupakan simbol dari sebuah cerita. Gerakan selyang, selayang dan main selendang merupakan simbol dimana gerakan tersebut mengacu pada bidadari yang ada sehingga disebut dengan Silampari. Silampari sangat melekat pada Musi Rawas bahkan sebelum pemekaran Silampari menjadi sebuah identitas dari masyarakat Musi Rawas. Makna dari gerakan selyang, selayang bahkan main selendang adalah dimana bidadari turun dari kayangan untuk mandi dan bermain di bumi Musi Rawas.

\section{SIMPULAN}

Tari Piring Gelas adalah sebuah tarian tradisional yang ada di Kabupaten Musi Rawas. Tari Piring Gelas memiliki teks dan konteks yang mana tidak terlepas tetapi pandangan masyarakat yang ada di Kabupaten Musi Rawas hanya melihat teks nya saja. Dalam tari Piring Gelas tentunya memiliki konteks atau makna dari tarian tersebut, banyak makna yang terkandung dalam tari Piring Gelas dan tentunya memiliki banyak filosofi yang belum terlihat oleh masyarakat. Tari Piring Gelas memiliki konteks isi sebagai koreografi terdiri dari konteks isi sebagai tema gerak, konteks isi sebagai tema cerita dan konteks isi sebagai tema simbolik.

Konteks isi sebagai tema gerak tari Piring Gelas memiliki tema umum kesabaran dalam menarikan tari Piring Gelas secara bertumpuk, kesabaran menaikkan piring dan gelas penuh dengan konsentrasi. Konteks isi sebagai tema gerak, pada tari Piring Gelas gerak- gerak diantaranya Gerak Hormat Salam, Selyang, Selayang, Main Selendang, Mengangkat Piring, Berputar, Transisi, Naik Piring. 
Konteks isi sebagai tema cerita tari Piring Gelas memiliki tema cerita tentang ketenangan dan konsentrasi/titik fokus dalam menginjak piring dan kesabaran dalam menaikkan Piring dan Gelas secara bertingkat. Tidak adanya konflik dalam tari Piring Gelas adanya klimaks ketika penonton melihat bagaimana Piring Gelas tersebut tidak jatuh ketika dinaikkan oleh penari dan ada rasa ketegangan dalam menarikan maupun menonton tari Piring Gelas tersebut.

Konteks isi sebagai tema simbolik yang ada di tari Piring Gelas memiliki simbol diantaranya aspek-aspek yang mendukung sebagai tema simbolik adalah kostum/ tata rias dan busana, tempat panggung, penari, properti, serta gerak serta dalam tari Piring Gelas di Kabupaten Musi Rawas.

\section{DAFTAR PUSTAKA}

Hadi. Y Sumandiyo, 1996. Aspek-aspek Dasar Koreografi Kelompok. Yogyakarta: Manthili Rochayati, Rully. 2014. Sejarah dan Analisis Tari. Palembang : Komunitas Titik Awal ,dkk. 2016. Menuju Kelas Koreografi. Palembang : Komunitas Lumbung Kreatif Sartono. 2014. Pengantar Pengetahuan Kesenian. Palembang : Universitas PGRI Palembang Widyastutieningrum, Sri Rochana dan Wahyudiardo, Dwi. 2014. Pengantar Koreografi. Surakarta. Isi Press Surakarta. 